\title{
Mengelola Pariwisata-Bencana: \\ Perlunya Perubahan Paradigma Pengeloaan Pariwisata \\ Dari Adaptive Governance Menuju Collaborative Governance
}

\author{
Muchamad Zaenuri \\ Universitas Muhammadiyah Yogyakarta, Yogyakarta \\ Email: e_zaenuri@yahoo.co.id
}

\begin{abstract}
Abstrak
Tulisan ini bertujuan mendeskripsikan perlunya tata pemerintahan (governance) yang dapat mengelola pariwisata pasca bencana secara efektif. Pengelolaan pariwisata pasca bencana ternyata harus perlu ada penanganan khusus, dalam kontek governance perlu adanya perubahan paradigma dari yang bersifat adaptif menjadi kolaboratif. Penanganan bencana alam dapat direspon dengan penerapan paradigma adaptfif governance sedangkan pengelolaan pariwisata pasca bencana harus menggunakan paradigma kolaboratif governance. Kolaboratif governance sebagai jawaban untuk keberlanjutan dari pariwisata yang berbasiskan pada bencana bercirikan saling berbagi manfaat dan resiko serta penggabungan sumberdaya diantara ketiga pilar governance.
\end{abstract}

Kata Kunci :

Tourism Disaster Management, Adaptive Governance, Collaborative Governance, Sleman Regency.

\section{Pendahuluan}

Pariwisata merupakan salah satu sektor terbesar di dunia sebagai pembangkit ekonomi, namun keberadaannya sangat rentan terhadap bencana baik yang disebabkan oleh alam atau manusia itu sendiri. Pariwisata adalah industri yang selalu 'dihantui' oleh krisis dan bencana, bahkan bisa dikatakan sangat sensitif dan rapuh karena sangat mudah untuk dipengaruhi oleh perubahan-perubahan maupun kejadian-kejadian yang ada di sekelilingnya (Henderson, 1999: 107-120). Yang paling penting karena keputusan perjalanan wisata dimulai dari niat manusia, sehingga rentan terhadap persepsi risiko dan fluktuasi lingkungan. Sebagian besar manusia akan melakukan perjalanan wisata apabila destinasi yang dikunjungi terbebas dari bencana, gangguan keamanan dan tentu saja untuk bersenang-senang. Selain itu, bencana merupakan kejadian yang tidak terduga serta tidak dapat dihindari muncul dalam bentuk dan intensitas yang berbeda, oleh karena itu kebangkitan pariwisata ditandai dengan kompleksitas dan beberapa kriteria yang bertentangan dengan bencana (Wickramasinghe, 2008).

Pada akhir tahun 2010 banyak obyek dan daya tarik wisata (ODTW) dan beberapa wilayah di Kabupaten Sleman terkena dampak bencara alam erupsi Gunung Merapi. Dampak dari bencana erupsi Merapi tersebut terhadap pariwisata tidak bisa dihindari dan bersifat sangat mendalam, di Kabupaten Sleman sektor pariwisata merupakan sektor yang paling lambat untuk melakukan recovery apabila dibandingkan dengan sektor yang lain dalam menghadapi datangnya bencana (Nurmaladewi, 2012). Peristiwa bencana telah merubah tata pemerintahan (governance), sementara ini governance bergerak secara adaptif seiring dengan datangnya bencana dengan penekann pada mitigasi bencana. Pemerintah dengan segala daya dan upaya membuat suatu kebijakan dan pengaturan untuk mitigasi bencana, masyarakat bahu membahu dengan lembaga swadaya masyarakat mencoba mempertahankan diri dan bangkit keluar dari kesulitan sebagai dampak bencana, sedangkan industri berusaha membantu dengan berbagai program CSR (Corporate Social Responsibility). Di balik datangnya bencana tersebut sebenarnya bisa muncul potensi wisata baru yang cukup menarik untuk dijadikan sebagai obyek 
dan daya tarik wisata (ODTW) sebagai dampak dari terjadinya bencana tersebut (Hardjito, 2011: $15)$.

Muncul dan tumbuhnya kegiatan pariwisata tidak lain karena di wilayah tersebut terdapat obyek yang spesifik dan unik, tidak ada di tempat lain dan menarik untuk dikunjungi. Sebagaimana diketahui bahwa wisata mempunyai hakekat : keunikan, kekhasan, perbedaan, orisinalitas, keaneka ragaman, dan kelokalan (Inskeep, 1994:12) sehingga menarik orang untuk melakukan perjalanan wisata. Dampak dari suatu bencana biasanya menarik untuk dikunjungi, pertama karena alasan kemanusiaan untuk menolong sesama, tetapi berikutnya dapat dijadikan sebagai "tontonan" karena memang spesifik dan unik. Bagi orang yang ingin mengetahui kondisi akibat dari bencana merasa iba dan juga "terhibur", tetapi bagi masyarakat yang dikunjungi dan masih merasa dirundung malang akan merasa sebagai obyek tontonan. Pengelolaan pariwisata selama ini memang sudah melibatkan tiga pilar governance namun sebagian besar masih bersifat adaptif dalam menghadapi datangnya bencana. Adaptasi dilakukan dengan penyesuaian kebijakan dan mengelola ketidak pastian yang disebabkan oleh bencana agar pariwisata masih tetap bisa berjalan (Nurmaladewi, 2012).

Kemampuan adaptif ini terutama dilakukan oleh pemerintah untuk mengambil kepemimpinan dalam pembentukan kebijakan dan untuk memberikan pengaturan kelembagaan yang kemudian dilanjutkan dengan tindakan (Eakin dan Lemos 2006), hal ini telah meningkatkan minat dalam menentukan bentuk yang tepat dari pemerintahan untuk adaptasi yang efektif. Studi lain tentang adaptasi sudah dilakukan oleh Eakin, et.al (2011:338-351) dalam kontek perubahan iklim. Hasil dari studi tersebut menununjukkan bahwa keberhasilan lembaga dan organisasi masyarakat dalam membangun kapasitas adaptasi terletak pada faktorfaktor seperti kendala pada pengambilan keputusan yang dilakukan oleh aktor politik, kesesuaian antara tanggung jawab lembaga dengan ekosistem, dan pengambilan keputusan untuk memfasilitasi masyarakat beradaptasi. Nelson (2007) dan Olsson (2007) telah melakukan pengamatan dan menunjukkan bahwa pergeseran dalam kebijakan juga memiliki implikasi untuk kerangka kelembagaan dan kapasitas adaptif.

Hingga sekarang relatif masih sedikit studi tentang bagaimana terjadi pergeseran dalam model pemerintahan dalam menghadapi perubahan yang berlangsung cepat, bencana merupakan perubahan yang berlangsung cepat dan membawa dampak yang besar terhadap pariwisata. Respon yang paling cepat dalam menghadapi perubahan yang disebabkan bencana adalah dengan menerapkan prinsip adaptif governance. Secara umum praktek penyelenggaraan pemerintahan baik di negara industri maupun di negara berkembang telah dipengaruhi oleh prinsip-prinsip "Good Governance", memang sudah banyak penelitian tentang tata kelola adaptasi dari governance namun sebagian besar dalam rangka merespon perubahan kebijakan (Eakin, 2011).

Pengelolaan bencana dalam kontek governance masih relevan melalui pendekatan adaptif, tetapi pengelolaan bencana yang dikaitkan dengan pariwisata tidak cukup hanya dengan pendekatan adaptif. Adaptif governance akan menghasilkan tata kelola yang responsif tetapi belum bisa bersifat kompetitif dan promotif. Recovery dan rekonstruksi bencana yang dibarengi dengan aktivitas kepariwisataan belum banyak dijadikan bahan kajian. Hingga sekarang ini kajian tentang kebangkitan pariwisata setelah datangnya bencana belum banyak dilakukan. Kerangka kerja manajemen bencana yang tersedia di literatur sebagian besar berisi daftar preskriptif karakteristik bencana dan penanggulangannya. Sampai saat ini, belum ada kajian yang sistematis berdasarkan konsep teoritis dan teknik analisis yang mendalam untuk mencari format recovery yang sekaligus memikirkan prospek pariwisata.

Untuk mengatasi kekurangan ini perlu dikaji kemungkinan perubahan paradigma dari adaptif governance menjadi kolaboratif governance sebagai wujud dari mode pemerintahan yang mengubah bencana menjadi pariwisata. Paparan dimulai dengan diskusi konseptual tentang konsep governance, adaptif governance dan kolaboratif governance. Selanjutnya, dieksplorasi 
literatur tentang pengelolaan bencana yang dikaitkan dengan pariwisata, termasuk perlunya perubahan tata kelola pengaturan yang mempengaruhi kemampuan masyarakat dan industri untuk berkolaborasi merubah bencana menjadi pariwisata. Setelah dihadirkan studi kasus, kemudian ditarik kesimpulan tentang bagaimana kolaboratif governance menjadi model pemerintahan yang paling cocok untuk menghadapi bencana dan sekaligus merubahnya menjadi bermakna pariwisata.

\section{Konsep Governance, Adaptif Governance dan Kolaboratif Governance}

Konsep governance ini lahir sebagai reaksi dari ketidak berhasilan konsep new managerialism (Saint-Martin, 2000), new public management (Andrisani, 2002) dan new public management old and new (Lynn, 2006) untuk mewujudkan administrasi publik yang berkeadilan sosial dan berorientasi pada kepentingan masyarakat. Konsep new managerialism dari Saint-Martin (2000:8) pada prinsipnya beranggapan bahwa kinerja sektor publik dapat meningkat bila diterapkan prinsip-prinsp manajerial sebagaimana perusahaan swasta. Banyak praktisi dari sektor swasta dijadikan sebagai konsultan dengan pertimbangan bahwa mereka lebih profesional bila dibandingkan dengan manajer publik. Penggunaan konsultan dan ideide mereka memberi kredibilitas kebijakan managerial karena mereka berasal dari sektor swasta. Konsep new public management dari Andrisani (2002:8) yang lebih mengadopsi prinsip-prinsip pasar untuk memperoleh efisiensi di sektor publik sebagaimana perusahaan swasta. Dan konsep public management old-new yang dikemukakan oleh Lynn (2006:1-17) juga termotivasi untuk menerapkan nilai-nilai dan instrumen sektor swasta agar diperoleh efisiensi dalam memberikan pelayanan dan keadilan kolektif, demikian juga harus ada proses transformasi warga yang aktif untuk menjadi konsumen.

Bertolak dari beberapa kegagalan yang dialami oleh konsep manajemen publik tersebut maka perlu dirumuskan kembali paradigma yang bisa memenuhi keadilan sosial dan berorientasi kepada masyarakat. Beberapa paradigma setelah itu muncul antara lain yang oleh Denhardt \& Denhardt (2007) disebut dengan new public service, dalam literatur Administrasi Publik dikenal juga dengan paradigma governance (Denhardt, 2007), public governance (Bovaired \& Loffler, 2009), adaptive governance ( Eakin, 2009), dan collaborative governance (Ansell \& Gash, 2007).

Konsep governance sebenarnya lebih komplek jika dibandingkan dengan government (Pierre, 2000:3-4) karena dalam governance terdapat tiga komponen/pilar, yaitu pemerintah, dunia usaha (swasta/parivat) dan masyarakat sipil (civil society). Hubungan diantara ketiganya harus dalam posisi sejajar, setara dan saling mengontrol (check and balances), untuk menghindari penguasaan atau eksploitasi oleh satu komponen terhadap komponen yang lain. Pergeseran government ke governance dimaksudkan untuk mendemokratisasi administrasi publik. Government menunjuk pada institusi pemerintah terutama dalam kaitannya dengan pembuatan kebijakan. Sementara itu, governance menunjuk pada keterlibatan non governmental organization (NGO), kelompok-kelompok kepentingan dan masyarakat; disamping institusi pemerintah dalam pengelolaan kepentingan umum, terutama dalam proses perumusan dan pelaksanaan kebijakan publik. Konsep governance memperhitungkan seluruh aktor dan area kebijakan yang berada di luar "pemerintah atau eksekutif" yang terlibat dalam proses pembuatan kebijakan (Syafri, 2012:180).

Koiman (1993:9) memandang governance sebagai subuah struktur yang muncul dalam sistem sosial-politik sebagai hasil dari tindakan intervensi interaktif diantara berbagai aktor yang terlibat. Sesuai dengan karakteristik interaksi antara pemerintah, privat dan masyarakat yang cenderung bersifat plural maka konsep governance tidak bisa dibatasi pada salah satu unsur pelaku atau kelompok pelaku tertentu saja. Dalam kontek penyelenggaraan pemerintahan yang baik perlu adanya peran yang setara antara pemerintah, privat dan masyarakat (Nisjar, 1997:119). Implikasi penting dari interaksi yang bersifat kesetaraan tersebut adalah adanya 
pelimpahan tanggung jawab dan akuntabilitas dalam penyediaan barang dan pelayanan publik dari pemerintah kepada pihak swasta dan masyarakat. Hal ini berawal dari semakin terbatasnya peran pemerintah dalam menyediakan barang publik dan pelayanan publik yang disebabkan dengan semakin menurunnya kualitas pelayanan publik (Dwiyanto, 2002:5). Salah satu cara untuk meningkatkan kualitas tersebut adalah dengan melibatkan semaksimal mungkin peran swasta dan masyarakat. Konsep governance yang melibatkan tiga pilar tersebut sudah sekian lama mengilhami para penyelenggara pemerintahan.

Perkembangan lebih lanjut dari konsep ini adalah bahwa governance tidak hanya sebagai dasar konseptual dalam penyelenggaraan pemerintahan dalam kondisi normal saja tetapi juga dalam rangka merespon perubahan lingkungan (Budiati, 2012), sehingga muncul konsep adaptif governance. Prinsip adaptif governance adalah menerapkan prisip-prinsip governance dengan mengacu pada perubahan lingkungan yang terjadi. Konsep ini dipakai dalam rangka untuk menjelaskan kemampuan adaptasi governance dalam menghadapi tantangan atau hambatan eksternal. Studi tentang adaptif governance cukup menarik para sarjana terutama dalam merespon perubahan iklim dan ekologi (Folke, 2005; Gunderson, 2006; Young, 2006). Dari berbagai tulisan tersebut dapat disimpulkan bahwa adaptif goverance merupakan satu model pemerintahan yang berusaha untuk menyesuaikan dan merespon perubahan dengan memperhatikan prinsip-prinsip tata pemerintahan yang baik. Dimensi yang harus diperhatikan untuk implementasi adapatif governance menyangkut informasi, kebutuhan politik dan sumberdaya (Watson, 2011).

Untuk menghadapi bencana dan sekaligus mengembangkan kepariwisataan, konsep adaptif governance ini dirasa belum cukup, perlu adanya mode pemerintahan yang lebih progresif. Konsep governance yang lebih akseleratif ini bisa dalam bentuk kolaboratif governance, hal ini dikarenakan melibatkan bentuk kerjasama antara insitusi pemerintah, swasta dan masyarakat bukan hanya memiliki tujuan atau kepedulian yang sama pada suatu permasalahan/isu tertentu, tetapi keduanya juga saling berbagi sumberdaya, resiko, tanggungjawab, dan manfaat (Dwiyanto, 2012: 256). Sifat kolaborasi yang seperti ini membuat orientasi pada kepentingan jangka panjang dan memerlukan daya tahan dan interaksi yang cukup tinggi dari kedua pihak.

Awal mula konsep ini dipakai untuk menjelaskan proses pembangunan yang akseleratif (Zadek, 2007), dimana target-target pembangunan harus dicapai dengan waktu yang sesingkat mungkin sehingga perlu adanya partisipasi dan kerjasama dari seluruh stakeholders. Kolaboratif governance biasanya digunakan untuk mengatasi permasalahan yang kompleks daripada masalah sosial sederhana (Imperial, 2005), solusi kolektif yang dihasilkan melalui kolaborasi pengambilan keputusan di antara berbagai pemangku kepentingan. Masalah yang lebih kompleks biasanya membutuhkan sebuah forum pemerintahan yang lebih inklusif kolaboratif dalam rangka untuk merespon kebutuhan politik, sumberdaya, dan informasi terkait (Olsson, Folke, \& Hahn, 2004).

Konsep kolaboratif governance ini sebenarnya sudah memperoleh dasar yang kuat karena sebelumnya telah diberi arahan oleh Cullen (2000) tentang perlunya transisi pemerintahan untuk lebih cepat dalam mengelola perubahan dengan didasarkan pada konsensus diantara tiga pilar governance. Dan yang paling mutakhir adanya suatu rumusan mode pemerintahan yang merupakan pembaharuan dari konsep gonvernance yang lama, yaitu apa yang disebut sebagai New Public Governance (Osborne, 2010). Konsep ini memberi dasar pijakan yang lebih kuat lagi bagi keberadaan kolaboratif governance karena pada konsep ini didasarkan pada konsep institusional dan jaringan (network theory) dengan fokus pada organisasi beserta lingkungannya (Osborne, 2010:10).

Pada perkembangan lebih lanjut menarik bagi sarjana lain (Ansell, 2007) untuk memahami secara komprehensif tentang kolaboratif governance ini. Dengan tujuan mengelaborasi model kontengensi kolaboratif governance dia melakukan studi meta-analisis 
terhadap 137 kasus governance yang ada tentang tata kelola kolaboratif. Dari hasil studi literatur tersebut dapat disimpulkan bahwa kolaboratif governance merupakan suatu tata kelola yang mengatur satu atau lebih lembaga-lembaga publik yang secara langsung terlibat baik negara maupun non-negara, termasuk pemangku kepentingan, dalam proses pengambilan keputusan kolektif yang bersifat formal, berorientasi konsensus dan musyawarah. Hal ini senada dengan yang dikonsepkan oleh Cullen (2000) perlu adanya konsensus diantara pilar governance dalam menghadapi transisi menuju kompetitif governance. Tujuan dari kolaborasi tersebut untuk membuat atau mengimplementasikan kebijakan publik dan mengelola program publik atau aset agar dapat mengatasi permasalahan yang komplek secara lebih cepat didasarkan pada jaringan yang kuat.

Dalam kerjasama kolaboratif masing-masing pihak diikat oleh adanya satu kepentingan bersama untuk mencari solusi terhadap masalah atau isu tertentu, yang dirasakan oleh para pihak sangat mengganggu kepentingannya. Kemauan untuk melakukan kerjasama muncul karena adanya keinginan untuk mencari solusi terhadap masalah yang dirasakan bersama oleh suatu organisasi publik dengan mitranya dari organisasi di sektor privat. Keduanya merasa bahwa masalah atau kepentingan tersebut dapat diselesaikan secara lebih mudah apabila mereka secara bersama-sama bekerja untuk mencari solusi terhadap masalah atau kepentingan bersama tersebut. Masalah atau kepentingan bersama menjadi sumber inspirasi dan motivasi bagi perkembangan kolaborasi antara organisasi publik, privat dan organisasi kemasyarakatan (Dwiyanto, 2012:253).

Sink (1998) sebagaimana dikutip oleh Dwiyanto (2012:254) menjelaskan kerjasama kolaboratif sebagai "sebuah proses dimana organisasi-organisasi yang memiliki suatu kepentingan terhadap satu masalah tertentu berusaha mencari solusi yang ditentukan secara bersama dalam rangka mencapai tujuan yang mereka tidak dapat mencapainya secara sendirisendiri”. Dengan menggunakan konsep tersebut maka kerjasama antara organisasi publik dan lembaga non pemerintah yang bersifat kolaboratif memiliki beberapa ciri antara lain yaitu: kerjasama bersifat sukarela, masing-masing pihak memiliki kedudukan yang setara, masingmasing juga memiliki otonomi dan kekuasaan untuk mengambil keputusan secara independen walaupun mereka sepakat untuk tunduk pada kesepakatan bersama, dan para pihak yang bekerjasama memiliki tujuan yang bersifat transformasional atau memiliki keninginan untuk meningkatkan kapasitas sitemik dengan menggabungkan sumberdaya yang mereka kuasai.

Agranoff dan McGuire (2003) sependapat bahwa pemerintah harus memadukan kapasitas yang dimilikinya dengan kapasitas pihak lain seperti warganegara dan berbagai aktor non pemerintah agar menjadi efektif dalam memecahkan rumitnya masalah plbik yang dihadapi. Jika kapasita kolaboratif adalah kunci keberhasilan bagi pemecahan masalah dalam jangka panjang maka harus dikenali persyaratan dasar bagi proses kolaboratif, atau bagaimana mengelola proses tersebut menjadi berhasil. Bardach (2001) menunjukkan tentang pentingnya pengembangan managerial untuk membangun collaborative capacity, sedangkan Miller (1992) dan Weber (1998) mengisyaratkan perlunya entrepreneur leader yang mampu membangun dan memelihara trust dan meyakinkan partisipan bahwa mereka dapat memperoleh lebih melalui kolaborasi ketimbang melakukannya sendirian. Khademian dan Weber (2003) mengeksplorasi praktek-praktek yang berkaitan dengan keberhasilan membangun kapasitas kolaboratif dari para manajer.

Manajemen kolaboratif yang mampu memberdayakan birokrasi masih kurang mendapat perhatian yang memadai karena tidak ada visi yang jelas dan juga karena hambatan peraturan pelaksanaan yang bersifat teknis (Muhammad, 2009). Padahal manajemen kolaboratif mampu menjadikan birokrasi berkinerja lebih baik dan institusi yang menjalankannya mendapat banyak keuntungan, diantaranya : 1) dapat dibentuk kekuatan yang lebih besar sehingga memiliki kemampuan yang lebih besar dalam mengatasi permasalahan yang kompleks, 2) dapat dicapai kemajuan yang lebih tinggi karena adanya pertukaran informasi, pengetahuan dan technical 
know-how, 3) kolaborasi menjadi lebih berdaya, 4) dapat mereduksi dan mencegah konflik, 5) mampu menubuhkan keadilan dan saling percaya, 6) mendorong upaya keberlanjutan pemecahan masalah secara bersama, dan 7) mamp mengikis ego daerah dan ego sektoral (Keban, 2007, dalam Dwiyanto, 2012:270).

Dari diskusi konsep tersebut dapat dibuat suatu klasifikasi yang membedakan ciri dari kedua konsep governance tersebut.

\begin{tabular}{llll}
\hline $\begin{array}{l}\text { Konsep Governance/ } \\
\text { Dimensi implementasi }\end{array}$ & Kebutuhan politik & Informasi & Sumberdaya \\
\hline $\begin{array}{l}\text { Adaptif Governance } \\
\text { Kolaboratif Governance }\end{array}$ & $\begin{array}{l}\text { Konsensus } \\
\text { Sinergis }\end{array}$ & $\begin{array}{l}\text { Sesuai kebutuhan } \\
\text { Untuk pengembangan }\end{array}$ & $\begin{array}{l}\text { Penyesuaian } \\
\text { Jaringan }\end{array}$ \\
\hline
\end{tabular}

\section{Manajemen Pariwisata Pasca Bencana}

Sebagian besar teori manajemen pada mulanya diasumsikan pada kondisi yang relatif stabil dalam lingkungan internal dan eksternal organisasi, oleh karena itu tidak menyediakan dasar yang kuat untuk mengatasi perubahan dan krisis (Booth, 1993). Jika implikasi dari perubahan dianggap sebagai suatu tantangan yang harus dihadapi secara bertahap dan relatif dapat diprediksi serta bukan merupakan perubahan mendadak, maka dapat dijadikan sebagai ujian bagi kemampuan organisasi untuk mengatasinya. Tetapi tidak selamanya perubahan itu datangnya bisa diprediksi, situasi seperti ini dapat digambarkan sebagai bentuk krisis atau bencana, bukan tantangan. Salah satu perspektif tentang sifat krisis disampaikan oleh Selbst (in Booth, 1993), yang menganggap krisis sebagai suatu kegagalan untuk bertindak dan mengganggu fungsi organisasi untuk mencapai tujuannya, kelangsungan hidupnya (survival), atau yang memiliki efek merugikan. Sedangkan Carter (1991) mendefinisikan bencana sebagai suatu peristiwa alam atau buatan manusia yang datangnya secara tiba-tiba atau mendadak dan dampaknya sangat hebat sehingga masyarakat yang terkena dampak harus merespon dengan mengambil langkah-langkah luar biasa. Dalam mensikapi krisis dan bencana ini, Booth (1993) memberikan penekanan tentang perlunya langkah-langkah yang luar biasa untuk merespon perubahan yang terjadi dengan mengacu pada kebutuhan non-rutin, disamping itu perlu diatasi tekanan yang datang tiba-tiba dengan kemampuan adaptif. Dengan demikian, krisis dan bencana digambarkan sebagai suatu situasi yang dihadapi oleh individu, kelompok atau organisasi yang mereka tidak mampu mengatasi dengan menggunakan prosedur rutin normal dan terjadi tekanan besar yang disebabkan oleh perubahan mendadak (Booth, 1993, p. 86) .

Bencana dan krisis disamping dihadapi oleh organisasi, tidak kalah pentingnya adalah bagaimana respon masyarakat dalam mensikapi datangnya bencana tersebut. Berbagai tindakan dari individu atau masyarakat yang terpengaruh oleh datangnya bencana yang mendadak sebagian besar bersifat menerima dan menyesuaikan dengan lingkungan yang ada (Hardjito, 2011:12). Penyesuaian yang dilakukan masyarakat lebih banyak ditunjukkan dengan berbagai perilaku gotong royong saling membantu dan membenahi kerusakan yang terjadi akibat bencana (Suyatno, 2011). Solidaritas mekanis tumbuh diantara kelompok-kelompok masyarakat (Usman, 2011). Bencana yang datang direspon oleh organisasi maupun masyarakat secara umum bersifat adaptif.

Setelah bencana berakhir mulai ada kegiatan pariwisata, pariwisata tidak cukup hanya direspon dengan adaptif saja tetapi harus lebih kolaboratif. Pengelolaan pariwisata pada situasi normal tentu saja akan berbeda dengan situasi pasca bencana. Pada situasi normal, kenyamanan dalam melakukan aktivitas kepariwisataan merupakan kunci sukses bagi terciptanya industri pariwisata berkelanjutan (Poirier, 1997) dan dibutuhkan peran pemerintah baik secara langsung maupun tidak langsung (Wilson et al, 2001). Peran pemerintah berupa menggerakkan sumberdaya yang tersedia untuk mewujudkan pembangunan berkelanjutan (Bramwell, 2006). 
Pengelolaan pariwisata pasca bencana harus lebih kompetitif dibandingkan dengan kondisi normal. Melalui penelitian disertasinya, Poon (1989) mengemukakan mengenai aspek kompetisi di bidang kepariwisataan mencakup 4 aspek yaitu meletakkan kekuatan penarik pada aspek lingkungan, menjadikan sektor pariwisata sebagai leading sector, memperkuat saluran distribusi dan pemasaran, dan membangun sektor privat yang dinamik dan kuat sebagai pihak penyedia industri pariwisata. Dari keempat aspek ini tentu saja tidak bisa hanya dilakukan oleh pemerintah saja, perlu adanya dukungan dari industri dan masyarakat. Agar ketiga komponen tersebut dapat secara cepat mengelola pariwisata pasca bencana perlu adanya network atau jaringan yang bersifat sinergis. Ozturk dan Eraydin (2010) melakukan penelitian di Turki menyimpulkan bahwa kemajuan pariwisata ditopang dengan adanya jejaring yang kuat diantara ketiga pilar governance.

\section{Pengelolaan Pariwisata Pasca Erupsi Merapi Di Sleman}

Peristiwa erupsi gunung Merapi yang terjadi pada tanggal 26 Oktober 2010 dan disusul dengan erupsi pada hari-hari berikutnya sampai awal bulan Nopember 2010 mengakibatkan berbagai permasalahan di kawasan Kecamatan Cangkringan dan Pakembinangun sebelah utara merupakan kawasan yang paling parah diterjang awan panas dan guguran lava gunung Merapi. Sejumlah sarana dan prasarana penunjang pariwisata di daerah tersebut luluh lantak ditelan ganasnya awan panas tersebut. Di samping itu, guguran abu vulkanik dan lahar dingin juga menyebabkan rusaknya beberapa sarana dan prasarana pariwisata di wilayah Kabupaten Sleman. Oleh karena itu, tidak hanya masalah pembangunan fisik saja yang dihadapi pasca bencana, akan tetapi menyangkut seluruh ekosistem yang ada di sana, baik keadaan alam maupun sosial masyarakat yang sangat memprihatinkan.

Peran pemerintah (khususnya Daerah Kabupaten Sleman) dalam melakukan mitigasi bencana sangat besar, pemerintah daerah Sleman melalui Badan Penanggulangan Bencana Daerah bekerjasama dengan lembaga terkait selalu merespon seiring dengan aktivitas gunung merapi (BPBD, 2011). Mulai dari fase tanggap darurat, recovery, rekonstruksi dan pengembangan. Setiap fase tersebut dilakukan dengan memperhatikan sumberdaya yang tersedia dan juga adanya dukungan politik dari pemerintah pusat maupun DPRD (Kedaulatan Rakyat, Edisi 13 Januari 2011). Terjadinya konsensus diantara para penyelenggara pemerintahan di daerah, instrumen APBD juga dipakai untuk membiayai korban bencana tersebut (BPKD DIY, 2011). Pengelolaan informasi tidak kalah pentingnya dilakukan mengingat kondisi status Gunung Merapi dari "Waspada, Siaga dan Awas" harus diinformasikan secara menyeluruh ke masyarakat. Demikian juga setelah pasca erupsi, pengelolaan informasi ini masih tetap berlanjut terutama dalam fase tanggap darurat dan recovery. Desiminasi informasi dilakukan sesuai dengan kebutuhan masyarakat, terutama dalam rangka mengurangi resiko akibat bencana. Sumberdaya yang ada dikelola dengan melalui penyesuaian terhadap kebutuhan masyarakat yang terkena bencana dan yang paling utama agar tidak semakin banyak memakan korban.

Prinsip governance dapat diimplementasikan dengan nuansa adaptif, semua pilar bekerja dengan menyesuaikan perubahan lingkungan yang terjadi. Pemerintah dengan melalui regulasinya menyesuaikan dengan perkembangan mitigasi bencana, pihak stakeholders melakukan tindakan penyelamatan maupun pertolongan kepada korban erupsi dengan menyesuaikan kemampuan dan kondisi yang ada. Dalam kontek kebencanaan peran governance sudah mencukupi, tetapi dalam upaya pengembangan pariwisata peran yang seperti itu kurang prospektif karena tidak menyadari bahwa bencana tersebut sebenarnya setelah selesai bisa bermakna pariwisata. Hal inilah yang menjadi anomali sehingga perlu adanya paradigma baru (Kuhn, 2008) agar mode pemerintahan lebih progresif dan mampu menangkap peluang di kemudian hari. Paradigma yang cocok untuk merespon hal yang seperti ini bisa diwujudkan dalam kolaboratif governance. 
Setelah pasca erupsi, untuk mengembalikan image atau citra suatu daerah pariwisata sebagai tempat yang unik, serta menumbuhkan rasa takjub bagi para wisatawan dan para pelaku wisata lainnya, Dinas Kebudayaan dan Pariwisata (Dispbudpar, 2011) melakukan koordinasi dengan para pemangku kepentingan yang terkait. Kegiatan yang dilakukan mencakup berbagai upaya, diantaranya adalah dengan melakukan berbagai kegiatan seperti promosi melalui jumpa pers atau pers release, booklet, poster dan berbagai media massa lainnya, pameran, dan expose. Disbudpar juga melakukan road show ke beberapa kota, yang dianggap sebagai daerah kantungkantung wisatawan, diantaranya Yogyakarta, Bali dan Jakarta untuk melakukan pembicaraan dengan beberapa kalangan (stakeholder) yang dapat membawa turis ke Sleman. Stakeholder tersebut diantaranya adalah Asosiasi Travel Seluruh Indonesia (Asita), PHRI (Pengusaha Hotel dan Restoran Indonesia), para guide, biro wisata, dan organisasi kepariwisataan Iainnya.

Peranan pemerintah dalam mengkomunikasikan setiap program pengembangan pariwisata sudah dilakukan secara maksimal. Program itu dapat disosialisasikan melalui berbagai saluran komunikasi yang ada sehingga implementasi program tersebut dapat lebih terarah. Bahkan berarti jika salah satu proyek sudah dilaksanakan berarti sudah selesai, harus ada sosialisasi lebih lanjut dan terjadwal. Ketika ada sebuah program mengenai perbaikan kawasan wisata, maka harus disosialisasikan kepada seluruh elemen pelaku wisata melalui Media Tourism Center yang memang ditujukan untuk wisatawan. Namun demikian, program ini akan berjalan lebih baik jika semua pihak mengetahuinya sehingga daya dukung para pelaku pariwisata kepada program yang sedang berjalan akan lebih tinggi dan membantu pelaksanaan program.

Masyarakat yang terkena dampak bencana diberi motivasi dari berbagai pihak untuk kuat menerima kenyataan dan juga dimotivasi kemungkinan akan adanya potensi wisata di daerah yang terkena erupsi tersebut. Pihak-pihak yang terkait secara sinergis melakukan pendampingan dan mengarahkan agar dapat menangkap peluang yang ada. Dokumentasi tentang bencana erupsi dikelola sedemikian rupa sehingga menjadi daya tarik tersendiri bagi wisatawan.

Model-model lain pengembangan kepariwisataan di Kabupaten Sleman pasca bencana erupsi gunung Merapi adalah melalui pengembangan wisata vulcano tracking di sekitar lereng Gunung Merapi. Paket wisata vulcano tracking di sekitar Merapi ini merupakan destinasi (tujuan wisata) yang cukup prospektif di kawasan ini. Untuk itu perlu menyiapkan segala sarana dan prasarana yang menunjang model wisata ini. Perlu dilatih para masyarakat lokal menjadi pemandu wisata vulcano tracking. Model wisata volcano tracking ini sangat berpotensi untuk menjadi daya tarik baru guna mendatangkan wisatawan minat khusus sekaligus sebagai upaya perintis untuk memulihkan pariwisata kabupaten Sleman pasca bencana erupsi Merapi. Sebagian besar sumberdaya dialokasikan untuk membuat jaringan yang diharapkan dapat merubah kondisi bencana tersebut menjadi tempat wisata yang cukup menarik.

Model pengembangan wisata juga dapat dilakukan melalui wisata gunung api atau volcano tour. Potensi wisata lava ini sangat besar karena lava akibat erupsi Merapi sangat besar dan luas serta menimbulkan keunikan yang tidak ada di daerah lain. Masyarakat pencinta alam akan menikmati dan menjelajahi guguran lava yang terjadi dengan menikmati keindahan alamnya. Wisata volcano ini dapat langsung diikuti wisatawan begitu status Merapi dinyatakan aman. Seperti halnya volcano tour Kaliadem menjadi daya tarik yang luar biasa setelah erupsi gunung Merapi tahun 2006. Banyak sekali wisatawan yang mengunjung wisata volcano di daerah tersebut. Obyek wisata volcano akan sangat menarik dan dapat menyedot kunjungan wisatawan dalam jumlah besar karena obyek wisata lava ini hanya ada di Kabupaten Sleman dan tidak ada duanya di Indonesia. Wisata ini memiliki keunggulan khusus karena wisatawan bisa langsung mendekati bekas-bekas terjangan awan panas dan lava Merapi yang sudah dingin.

Hingga sampai sekarang ini pengelolaan dampak dari erupsi merapi sudah bermakna pariwisata dan sudah berjalan, tetapi kalau dilakukan evaluasi mestinya akan lebih akseleratif apabila sejak awal sudah difikirkan akan perlunya paradigma kolaboratif governance. Hal ini 
patut dikedepankan karena mulai tahun 2012 ini angka kunjugan wisatawan semakin menurun (Kedaulatan Rakyat, 12 Agustus 2012) dan sebagian besar yang datang adalah wisatawan yang selalu baru, artinya tidak ada wisatawan yang merasa puas hingga akhirnya akan berkali-kali mengunjungi daerah volcano tour tersebut.

Sinergisitas diantara ketiga pilar sudah berjalan sedemikian rupa tetapi masih perlu adanya perbaikan. Pemerintah daerah telah melakukan kegiatan untuk pembenahan regulasinya, pihak swasta juga sudah mulai menjual produk-produk wisata yang berkaitan dengan keindahan Merapai pasca erupsi, dan masyarakat dengan berbagai daya upaya telah mendukung dengan membuat kelompok komunitas jeep dan trail untuk pelayanan kepada wisatawan.

Perlu adanya pembagian sumberdaya baik oleh pemerintah, swasta dan masyarakat untuk memberi pelayanan yang lebih baik kepada masyarakat. Kerjasama yang bersifat jangka panjang dan bernuansakan kemitraan akan lebih bisa memberi solusi ketimbang dengan pemberian pelayanan yang bersifat sendiri-sendiri. Pengembangan jejaring diantara stkeholder sudah mulai dilaksanakan. Paket-paket wisata minat khusus jelajah gunung Merapi dengan menggunakan jeep dan trail sudah mulai dikembangkan. Kolaborasi diantara masyarakat sebagai penyedia jasa wisata dan pihak swasta yang berfungsi sebagai biro perjalanan wisata sudah terjalin secara sinergis.

Pemerintah daerah khsususnya Dinas Kebudayaan dan Pariwisata melakukan fasilitasi yang berkaitan dengan pariwisata pasca erupsi Merapi. Mengingat sebagaian besar masyarakat yang terkena dampak erupsi awal mulanya berprofesi sebagai petani, maka Disbudpat bekerjasama dengan perusahaan wisata memberikan pelatihan dan pendampingan agar masyarakat bisa berperan aktif dalam penyediaan usaha dan jasa wisata. Demikian juga karena destinasi wisata sebagian besar berada di kawasan bekas pemukiman warga, maka pembenahan spasial yang berhubungan dengan tata ruang juga mendapatkan perhatian yang serius dari Disbudpar.

Praktek kolaboratif governance sudah berlangsung dengan melibatkan secara signifikan peran serta masyarakat sekitar kawasan Merapi yang terkena dampak langsung erupsi Merapi. Peran tersebut meliputi penyedia jasa wisata, operator jeep, operator trail, penjaja makanan dan souvenir dan sebagainya. Dengan dikeluarkannya Surat Rekomendasi dari Bupati Sleman Nomor 556/0063 tertanggal 12 Januari 2011 tentang Pengelolaan Kawasan Wisata Volcano Tour Merapi yang diperpanjang dengan Surat Rekomendasi Perpanjangan Nomor 590/590 tertanggal 8 Maret 2011 maka kawasan wisata tersebut sudah mulai jelas dalam pengelolaannya. Sebagai tindak lanjut dari surat bupati tersebut, melalui surat dari Sekda Sleman Nomor 556/0373 tentang Pengelolaan Kawasan Vulcano Tour Merapi semakin jelas bahwa pengelolaan kawasan tersebut diserahkan kepada Pemerintah Desa Umbulharjo dan pemerintah tersebut diharuskan untuk membentuk organisasi pelaksanana.

Berdasarkan surat dari sekda tersebut Kepala Desa Umbulharjo menindaklanjuti dengan membuat Peraturan Desa. Melalui Peraturan Desa Nomor 4 tahun 2012 tertanggal 12 April 2012 tentang Pengelolaan Kawasan Wisata Vulcano Tour Desa Umbulharjo, diatur beberapa hal yang berkaitan dengan pengelolaan volcano tour Merapi. Didalam perdes tersebut dibentuk tim pengelola kawasan wisata Volcano Tour di Desa Umbulharjo yang melibatkan tokoh masyarakat, pemuda dan perangkat desa setempat.

Tim pengelola inilah yang menjadi motor penggerak bagi pelayanan pariwisata di kawasan volcano tour Merapi. Tim ini bertugas untuk mengelola mulai dari merencanakan, memberi pelayanan, membuat laporan kepada pemerintah desa, dan sekalgus mengembangkan obyek wisata di kawasan volcano tour Merapi. Meskipun masih terjadi kendala namun hingga kini keberadaan dari pengelola ini cukup bisa menggerakkan kolaboratif governance dalam pengelolaan kawasan wisata volcano tour Merapi. 


\section{Kesimpulan}

Pengelolaan pariwisata pasca bencana ternyata harus perlu ada penanganan khusus, dalam kontek governance perlu adanya perubahan paradigma dari yang bersifat adaptif menjadi kolaboratif. Penanganan bencana alam dapat direspon dengan penerapan paradigma adaptfif governance sedangkan pengelolaan pariwisata pasca bencana harus menggunakan paradigma kolaboratif governance. Kolaboratif governance sebagai jawaban untuk keberlanjutan dari pariwisata yang berbasiskan pada bencana.

\section{Daftar Pustaka}

Agranoff, Robert, and Michael McGuire. (1998). "Multi-network managemnt Collaboration and the hollow state", Journal of Public Administration Research and Theory 1: 67-91.

Andrisani, P.J., Hakim, S. And Savas, E.S. (2002). The New Public Management: Lessons From Innovating Governors and Mayors, Kluwer, Massachusetts.

Ansell, Chris and Alison Gash. (2007). "Collaborative Governance in Theori and Practice", in Journal of Pablic Administrasi Research and Theory 18 : 543-571.

Badan Penanggulangan Bencana Daerah (BPBD) Kabupaten Sleman, 2011. Laporan Akuntabilitas Kinerja Instansi Pemerintah (LAKIP).

Badan Pengelola Keuangan Daerah (BPKD) Kabupaten Sleman, 2001, Laporan Akuntabilitas Kinerja Instansi Pemerintah (LAKIP).

Bardach, Eugene. (2001). "Developmental dynamic: Interagency collaboration as an emergent phenomenon", Journal of Public Administration Research and Theory 2: 149-164.

Boivard, T and Loffler E. (ed). (2009). Public Management and Governance. London : Routledge.

Booth, S. (1993). Crisis Management Strategy: Competition and Change in Modern Enterprises. New York: Routledge.

Bramwell, B. (2006). "Actors, Power and Discourses of Growth Limits", in Annals of Tourism Research 33(4):957-978.

Budiati, Lilin. (2012). Good Governance Dalam Pengelolaan Masalah Lingkungan, Jakarta : Graha Ilmu.

Carter, W.N. (1991). Disaster Management: A Disaster Manager's Handbook, Manila: Asian Development Bank.

Cullen, Ronald B, and Donald B. Chusman (2000). Transitions to Competitive Government,Speed, Consensus and Performance, New York : State University of New York Press.

Dinas Kebudayaan Dan Pariwisata Kabupaten Sleman (2011). Laporan Akuntabilitas Kinerja Instansi Pemerintah (LAKIP).

Denhardt and Denhardt. (2007). The New Public Service, Expanded Edition: Serving, Not Steering. New York : M.E. Sharpe, Armonk.

Dwiyanto, Agus. (2002). Reformasi Birokrasi Publik Di Indonesia. Yogyakarta : Pusat Studi Kependudukan dan Kebijakan Universitas Gadjah Mada.

Dwiyanto, Agus (2012). Manajemen Pelayanan Publik: Peduli, Inklusi dan Kolaboratif, Yogyakarta: Gadjah Mada University Press.

Eakin, Hallie and Lemos MC. (2006). "Adaptation and the State: Latin America and the challenge of capacity building under globalization", in Global Invironmental Change 1,p. 7-18.

Eakin, Hallie, Siri Eriksen, Per-Ove Eikeland and Cecilie Oyen. (2011). "Public Sector Reform and Governance for Adaptation: Implication of New Public Management for Adaptive Capacity in Mexico and Norwey", in Environmental Management Journal 47, p. 338351. 
Faulkner, Bill. (2001). "Towards a Framework for Tourism Disaster Management”, in Tourism Management $22: 135-147$.

Hardjito, Agus D, Jaka Sriyana dan Suhartini. (2011). "Recovery Pengembangan Wisata Pasca Bencana Erupsi Merapi Di Kawasan Kabupaten Sleman”, http://dppm.uii.ac.id

Henderson, J.C. (1999). "Tourism Management and the Southeast Asian Economic and Environmental Crises. A Singapore Perspective". Journal of Managing Leisure 4, p. 107-120. Tersedia online at: http://www.ingentaconnect.com. accessed 12 March 2006.

Imperial, M. T. (2005). "Using collaboration as a governance strategy". Administration \& Society, 37(3): 281-320.

Inskeep, Edward. (1994). National and Regional Tourism Planning, London : Routledge.

Koiman, Jan (ed). (1993). Modern Governance: New Government-Society Interactions. London : SAGE Publications.

Kuhn, Thomas S. (2008). The Structure of Scientific Revolutions, Peran Paradigma Dalam Revolusi Sains, (Terjemahan), Bandung: Remaja Rosdakarya.

Lynn, Jr, Laurence. E. (2006). Public Management : Old and New. New York : Routledge.

Muhammd, Fadel. (2009).”Energizing Bureaucracy Untuk Membangun Governance Di Sektor Publik : Suatu Pemikiran Awal", dalam Agus Pramusinto dan Wahyudi Kumorotomo, Governance Reform di Indonesia: Mencari Arah Baru Kelembagaan Politik yang Demokratis dan Birokrasi yang Profesional, Yogyakarta: Gava Media.

Nelson D, Adger WN, Brown K. (2007). "Adaptation to Environtmental Change : Contribution of a Resilience Framework", in Anual Review of Environmental and Resources 32 : 395 419.

Nisjar S, Karhi. (1997). "Beberapa Catatan Tentang Good Governance", dalam Jurnal Administrasi dan Pembangunan 2, h.119.

Nurmaladewi, Savitri, 2011. Wawancara pada tanggal 12 Pebruari 2011.

lsson, P., Folke, C., \& Hahn, T. (2004). "Social-ecological transformation for ecosystem management: The development of adaptive co-management of a wetland landscape in southern Sweden". In Ecology and Society, 9(4): 2-27.

Osborne, S.P., 2010. The New Public Governance? Emerging perspectives on the theory and practice of public governance. Oxon : Routledge.

Ozturk, Hilal Erkus and Ayda Eraydin. (2010). "Environmental Governance for Sustainable Tourism Development: Collaborative Network and Organization Building in the Antalya Tourism Region" in Tourism Management 31, p.113-124.

Pierre, Jon, and B. Guy Peters. (2000). Governance, Politics and the State. London: MacMillan Press Ltd.

Poon, Auliana. (1989). "Competitive Strategies for New Tourism" dalam C. Cooper (eds), Progress in Tourism Recreation and Hospitality Management, Vol. 1, London : Belhaven Press.

Poirier, Robert A. (1997). "Environmental Policy and Tourism in Tunisia", in Journal of Travel Research, Sage Publication, Winter, p.57-60.

Saint-Martin, D. (2000). Building the New Managerialist State, Oxford University Press, Oxford.

Suyatno, Hempry. (2011). "Ketahanan Masyarakat Pasca Erupsi Merapi”, dalam Kedaulatan Rakyat, Edisi 4 Januari 2011.

Syafri, Wirman (2012). Studi Tentang Administrasi Publik. Jakarta : Penerbit Erlangga.

Usman, Sunjoto. (2011). “Tinjauan Sosiologis Erupsi Merapi”, dalam Kedaulatan Rakyat, edisi 12 Pebruari 2011.

Watson, Thomas J. (2011). "Effective dan Adaptive Governance" in http://www.ppic.org/ content/pubs/report/R_211EHChapter8R.pdf 
Wickramasinghe, Vasantha S.K., 2008. "Analytical Tourism Disaster Management Framework for Sustainable Following a Sudden Calamity", Ph.D Dissertation, Division of Engeneering and Policy for Cold Regional Environment, Hokkaido University, Japan.

Wilson, Suzanne, Daniel R. Fesenmaier, Julie Fesenmaier and John C. Van Es. (2001). "Factor for Success in Rural Touris Development" in Journal of Travel Research, Vol 40, p.132138, diakses dari http://www.jtr.sagepub.com.

Zadek, Simon. (2011). "Collaborative Governance : The New Multilateralism for the 21st Century", in http://www.zadek.net/wp-content/uploads/2011/01/AccountAbility-ZadekCollaborative-Governance-Brookings-October-2007.pdf

Harian Kedaulatan Rakyat, Edisi 13 Januari 2011

Harian Kedaulatan Rakyat, Edisi 12 Agustus 2012 